\title{
Carbon-based secondary and structural compounds in Mediterranean shrubs growing near a natural $\mathrm{CO}_{2}$ spring
}

\author{
J. PENUELAS*, E. CASTELLS*, R. JOFFRE† and R. TOGNETTI \\ *Unitat d'Ecofisiologia CSIC-CREAF, Centre de Recerca Ecologica i Aplicacions Forestals (CREAF), Facultat de Ciències, \\ Universitat Autònoma, Bellaterra 08193 (Barcelona), Spain, $\dagger$ DREAM Unit, Centre d'Ecologie Fonctionnelle et Evolutive-CNRS, \\ 1919 route de Mende, 34293 Montpellier Cedex 5, France, †Dipartimento di Scienze Animali Vegetali e dell'Ambiente (SAVA), \\ Universitá degli Studi del Molise, via De Sanctis I-86100 Campobasso, Italy
}

\begin{abstract}
We studied carbon-based secondary and structural compounds (CBSSCs) in Myrtus communis, Erica arborea, and Juniperus communis co-occurring in a natural $\mathrm{CO}_{2}$ spring site and in a nearby control site in a Mediterranean environment. Leaf concentrations of phenolics and CBSSCs, such as lignin, cellulose, and hemicellulose, total nonstructural carbohydrates (TNCs), and lipids were measured monthly (phenolics) and every two months (the other compounds) throughout a year. There was a slight seasonal trend towards maximum concentrations of most of these CBSSCs during autumn-winter and minimum values during the spring season, particularly in Myrtus communis. For most of the CBSSCs and species, there were no consistent or significant patterns in response to the elevated $\left[\mathrm{CO}_{2}\right]\left(c .700 \mu \mathrm{mol} \mathrm{mol}^{-1}\right)$ of the spring site. These results were not due to a dilution effect by increased structural or nonstructural carbon. Therefore, in contrast to many experimental studies of $\mathrm{CO}_{2}$ enrichment, mainly conducted for short periods, there were no greater concentrations of phenolics, and, as in many of these studies, there were neither greater concentrations of the other CBSSCs. These results do not agree with the predictions of the carbon source-sink hypotheses. Possible causes of this disagreement are discussed. These causes include the complex heterogeneous environmental conditions and the variability of resource availabilities in the field, photosynthetic downregulation, and/or the homeostatic and evolutionary nature of organisms. These results suggest evolutionary adaptive responses to changes in $\mathrm{CO}_{2}$. They also suggest caution in attributing increased CBSSC concentrations to elevated $\left[\mathrm{CO}_{2}\right]$ at long-term scale in natural conditions, and therefore in their implications for plant-herbivore interactions and for decomposition.
\end{abstract}

Keywords: cellulose, Erica arborea, Juniperus communis, lignin, lipids, Myrtus communis, phenolics, total nonstructural carbohydrates

Received 28 April 2001 revised version received and accepted 6 August 2001

\section{Introduction}

Uncertainties regarding the effects of elevated $\left[\mathrm{CO}_{2}\right]$ on plant ecophysiology in general, and on plant chemical composition in particular, rise because predictions have mainly been extrapolated from studies on short-term exposure of plants in manipulated environments (greenhouses and growth chambers), without considering factors, such as long-term acclimation, species and

Correspondence: Prof. Josep Peñuelas, fax +34/93-5811312,

e-mail Josep.Penuelas@uab.es genotype responses, and the complex environmental field conditions (including heterogeneous resource availabilities). Moreover, vegetation is not likely to be suddenly subjected to a dramatic increase in atmospheric $\left[\mathrm{CO}_{2}\right]$ such as the one typically imposed in short-term $\mathrm{CO}_{2}$-enrichment experiments. Various physiological processes could adjust or acclimate to gradual increases in $\mathrm{CO}_{2}$ at different rates over periods ranging from hours to years, to generations (Eamus \& Jarvis 1989; Saxe et al. 1998). However, despite the potential long-term acclimation, few studies on $\mathrm{CO}_{2}$ have extended beyond a single growing season. Interestingly, in some of the few 
relatively long studies the initial reductions in the leaf concentrations of nitrogen $(\mathrm{N})$ and other elements have been found to gradually disappear over the forthcoming years (Peñuelas \& Matamala 1990; Peñuelas et al. 1997). Natural $\mathrm{CO}_{2}$ springs offer an opportunity to overcome these sources of uncertainty. They allow us to study longterm responses of entire plant communities to enriched $\left[\mathrm{CO}_{2}\right]$ in complex field conditions (Miglietta et al. 1993; Körner \& Miglietta 1994; Hättenshwiler et al. 1997; Peñuelas et al. 2001).

The steady increase in atmospheric $\mathrm{CO}_{2}$ concentrations is likely to affect biota by producing changes not only in plant growth and allocation, but also in plant-tissue chemical composition (Peñuelas \& Estiarte 1998; IPCC 2001). Among such composition changes, most sourcesink hypotheses assume that elevated $\mathrm{CO}_{2}$ concentrations promote a relative increase of carbon availability that is accumulated in TNCs and CBSSCs when the provided carbon amounts exceed growth requirements (when the source-sink ratio raises) (Bryant et al. 1983; Herms \& Mattson 1992; Peñuelas \& Estiarte 1998). These hypotheses thus predict a larger accumulation of carbon-based secondary and structural compounds (CBSSCs), like phenolics, terpenes, or structural polysaccharides (cellulose, hemicellulose, and pectin), at elevated $\mathrm{CO}_{2}$ concentrations (Peñuelas \& Estiarte 1998). Such changes could have significant consequences for ecosystem functioning, e.g. through plant-herbivore interactions (Lincoln et al. 1993; Lindroth et al. 1993) and plant litter decomposition (O’Neill \& Norby 1996).

However, experimental results on leaf chemistry only provide evidence of increases in concentrations of soluble phenolics and condensed tannins, but not in concentrations of other CBSSCs with various metabolic pathways (Peñuelas \& Estiarte 1998), and overall effects on litter quality appear smaller than it was initially thought (Ball 1997). The changes in soluble phenolics and condensed tannins seemed more evident when the concentrations were expressed on structural dry weight basis because the expression of concentration on a dry weight basis can mask or diminish the changes in the concentration of compounds. This happens especially in high- $\mathrm{CO}_{2}$ grown plants that typically have large increases in total nonstructural carbohydrates (TNCs) (Poorter et al. 1997; Koricheva et al. 1998), and specially in organs such as leaves with large daily TNC fluctuations due to TNC accumulation during light period and TNC export at night (Hendrix \& Grange 1991).

Plant communities of Mediterranean-type ecosystems are expected to be particularly sensitive to ongoing increases in concentrations of atmospheric $\mathrm{CO}_{2}$ (IPCC 2001). These Mediterranean plant communities are likely to face more severe drought conditions in the future due to the increase in mean temperature and potential evapotranspiration and to the concurrent decrease in precipitation at Mediterranean latitudes as forecasted by General Circulation Models (Kattenburg et al. 1996).

In this study, we compared leaf concentrations of phenolics and other CBSSCs, such as lignin, cellulose, and hemicellulose, TNCs, and lipids in Myrtus communis L., Erica arborea L., and Juniperus communis L.-Mediterranean shrubs growing in the proximity of a natural $\mathrm{CO}_{2}$ spring site-with those of comparable shrubs of the same species grown in a nearby control site exposed to ambient $\left[\mathrm{CO}_{2}\right]$. The objective of our research was to study changes in leaf concentrations of phenolics and other CBSSCs in response to $\mathrm{CO}_{2}$ enrichment during longterm growth in natural field conditions. Our questions were: (1) whether increased CBSSC concentrations occur at elevated $\left[\mathrm{CO}_{2}\right]$ or not (i.e. whether CBSSC concentrations follow the source-sink hypotheses or, alternatively, there are long-term adjustments or 'acclimation' of leaf CBSSC concentrations over a period of several generations growing on complex environmental natural conditions; and (2) if CBSSC concentrations do increase, whether they are general or particular for various compound classes and various plant species, and whether they are linked to changes in concentrations of total nonstructural carbohydrates (TNCs) or lipids.

\section{Materials and methods}

\section{Site description and plant material}

Leaf samples were obtained from Erica arborea, Myrtus communis, and Juniperus communis - the three common and widespread Mediterranean macchia shrub species growing near a natural $\mathrm{CO}_{2}$ spring called 'I Borboi' in Lajatico (Pisa, Italy) $\left(43^{\circ} 26^{\prime} \mathrm{N}, 10^{\circ} 42^{\prime} \mathrm{E}\right)$ that has been active for centuries (city council archives). A full description of the geology of the site can be found in Panichi \& Tongiorgi (1975). The $\mathrm{CO}_{2}$-enriched area extends over 0.7 ha. The studied coppiced stand is dominated by Quercus ilex L., Quercus pubescens Willd., and Arbutus unedo L. Several other tree species (e.g. Quercus cerris L. and Fraxinus ornus L.) are represented by scattered individuals. Shrubs include the species studied here, as well as Smilax aspera L., Cytisus scoparius L., Cistus salvifolius L., Genista sp., Ligustrum vulgare L., Pistacia lentiscus L., and Phillyrea latifolia $\mathrm{L}$. The $\mathrm{CO}_{2}$ spring site is located on the north-facing slope $(20 \%)$ of a hill near the bottom of a small valley about $200 \mathrm{~m}$ above sea level (Raiesi 1998a,b; Tognetti 1999). Almost pure $\mathrm{CO}_{2}$ emissions occur from a series of vents located along a narrow seasonal creek, and the $\left[\mathrm{CO}_{2}\right]$ tends to decrease upslope; see Tognetti et al. (2000a) for a map of the site. The vents emit small amount of $\mathrm{H}_{2} \mathrm{~S}$ (hydrogen sulfide), but their concentrations never exceed a level of $0.04 \mu \mathrm{mol} \mathrm{mol}{ }^{-1}$, which is not 
considered harmful to plants (Raiesi 1998a,b; Schulte 1998). Plants around the $\mathrm{CO}_{2}$ spring site are exposed to daytime $\left[\mathrm{CO}_{2}\right]$ of about $700 \mu \mathrm{mol} \mathrm{mol}{ }^{-1}$ throughout the year, with short-term variations between 500 and $1000 \mu \mathrm{mol} \mathrm{mol}{ }^{-1}$ depending on wind speed and convective turbulence. The $\left[\mathrm{CO}_{2}\right]$ varies little between different heights within the canopy (Hättenshwiler et al. 1997).

Leaf samples were collected from individuals growing close to the $\mathrm{CO}_{2}$ spring site. Control measurements were made at a site chosen along the same creek, about $150 \mathrm{~m}$ upstream; thus root systems of the sampled plants experienced similar soil environment. The area has noncalcareous, brown loamy clay soils developed from calcareous marl ( $\mathrm{pH} 6-7)$, with total soil $\mathrm{N}$ and $\mathrm{C} / \mathrm{N}$ ratio in the forest floor and mineral horizon $(0-10 \mathrm{~cm})$ being comparable in both the spring and control sites (Raiesi 1998a,b). The climate is typical Mediterranean, with cool, wet winters and hot, dry summers (Tognetti 1999). At both sites, six replicate shrubs of similar exposure were selected for each species and sampling month. Measurements were made on current year welldeveloped leaves from sunny shoots in the upper third of the canopy. The mean leaf longevity of the three species is 2-3 years, buds break in April-May, and leaf abscission also takes place in April-May. To avoid possible CBSSC differences due to phenological effects, we sampled plants and leaves of the same stage of development in the two sites.

\section{Leaf chemical composition}

Every month from October 1996 to September 1997, shoots were collected from six individuals (not necessarily the same ones every month) of each species (Erica arborea, Myrtus communis, and Juniperus communis) at each site $\left(\mathrm{CO}_{2}\right.$ spring and control), early in the morning. The shoot material was oven-dried at $60^{\circ} \mathrm{C}$ to constant weight (dry weight, DW). Thereafter, 10-12 leaves of the same stage of development were bulked for each plant at each sampling date and then ground to a fine powder in a mill. Phenolics were analysed every month and the rest of CBSSCs, TNCs, and lipids every two months.

Leaf concentrations of phenolics were measured on subsamples (about $50 \mathrm{mg}$ ) of ground leaves. Total phenolic compounds were analysed by the Folin-Ciocalteu method, improved by using a blank of polyvinylpolypyrrolidone (PVPP) (Marigo 1973). Polyvinylpolypyrrolidone removes phenolic compounds from the solution, and avoids overestimation of total phenolics due to nonphenolic Folin-Ciocalteu reactive compounds. Gallic acid was used as a standard to estimate concentrations of phenolic compounds.

Leaf concentrations of lignin, cellulose, hemicellulose, TNCs, and total lipids were determined on subsamples of ground leaves using near-infrared reflectance spectroscopy (see Joffre et al. 1992 and Damesin et al. 1997 for a description of the procedure). All samples were scanned with an NIRSystem 6500 spectrophotometer. The spectral and wet chemical database used to build calibration equations comprises leaves of 25 species, representing the diversity of the Mediterranean woody species collected by us from the Mediterranean areas of Portugal, Spain, France, and Italy, and includes part of the database of Meuret et al. (1993). The concentrations of fibre, total lipids, and TNCs in these calibration-set samples were determined using wet chemistry methods. Fibre fractions were determined using the Fibertec procedure (Van Soest \& Robertson 1985), total lipids were obtained by weighing the residue extracted by a chloroform-methanol mixture (Allen 1989) and TNC analysis was carried out following the method of Farrar (1993).

\section{Statistical analyses}

Within each species, two-way analyses of variance (ANOvA) with sampling date and site (with different $\left.\left[\mathrm{CO}_{2}\right]\right)$ as the main effects were conducted for all compound concentrations after testing for normality and homogeneity of variance. A repeated-measures analysis was not considered appropriate because we did not sample the same shrubs over the sampling time period. Differences amongst the three species were also tested with ANOvA. Statistical analyses were conducted using Statview 4.5 (Abacus Concepts Inc., Berkeley, CA, USA) and systAT 5.2 (systAT Inc., Evanston, IL, USA).

\section{Results and discussion}

There were significant differences amongst the species for most CBSSCs ( $P<0.01$, ANOva) (Figs 1 and 2). Myrtus communis had the greatest leaf concentrations of phenolics and the lowest leaf concentrations of hemicellulose (Figs 1 and 2). Erica arborea had the greatest leaf concentrations of hemicellulose, and the lowest leaf concentrations of TNCs. Juniperus communis had the greatest leaf concentrations of lignin, cellulose, and lipids, and the lowest leaf concentrations of phenolics (Figs 1 and 2).

There were various responses to site (and, therefore, $\left.\left[\mathrm{CO}_{2}\right]\right)$, depending on compounds and species. Foliar phenolic concentrations were $28 \%$ lower in the $\mathrm{CO}_{2}$ spring site than in the control site in Erica arborea. Foliar TNC concentrations were $13 \%$ greater in Myrtus communis, but on the contrary, $12 \%$ lower in Juniperus communis. Foliar lignin concentrations were 5\% greater in Juniperus communis. Leaf concentrations of hemicellulose were 19\% greater in Myrtus communis. For all other compounds and species there were no significant patterns in response to the elevated $\left[\mathrm{CO}_{2}\right]$ of the spring site (Figs 1 and 2). 


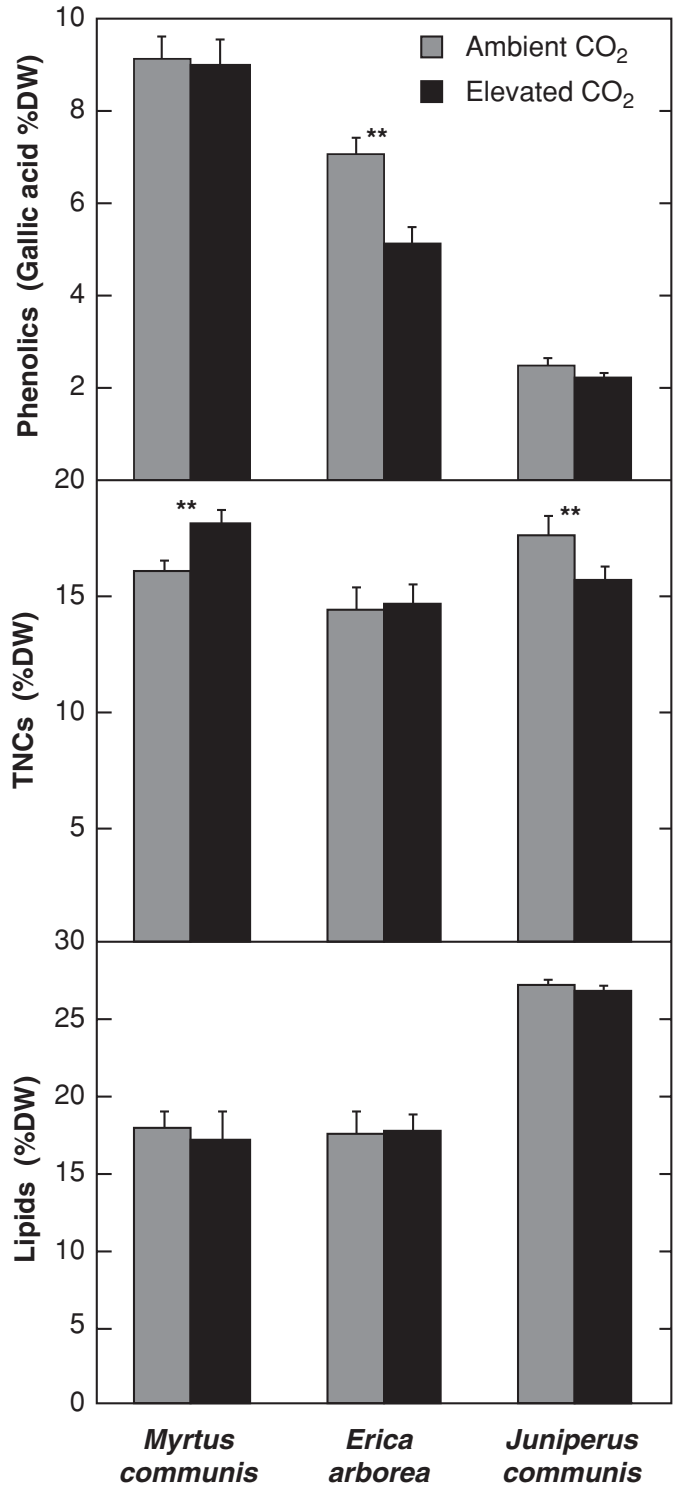

Fig. 1 Effects of elevated $\left[\mathrm{CO}_{2}\right]$ on annual average leaf phenolics (top), total nonstructural carbohydrates (TNCs) (middle), and lipid concentrations (bottom). Data presented as percent dry weight $(\% D W)$. Error bars indicate \pm SEM. $n=6$ month averages, calculated on three plants (10-12 leaves pooled together for each plant). ${ }^{* *} p<0.01$, ANOVA.

The concentrations of many CBSSCs differed significantly by sampling month (Fig. 3 for phenolics) as expected for leaves in various developmental stages (Peñuelas \& Estiarte 1998). However, the three shrub species did not display consistent seasonal changes for most CBSSCs, except for a slight trend towards minimum values in spring (youngest leaves) and maximum values in autumn-winter (mature leaves) (Fig. 3). This trend was the strongest for Myrtus communis. The analyses revealed some statistically significant interactions between $\mathrm{CO}_{2}$ enrichment and month (Fig. 3).

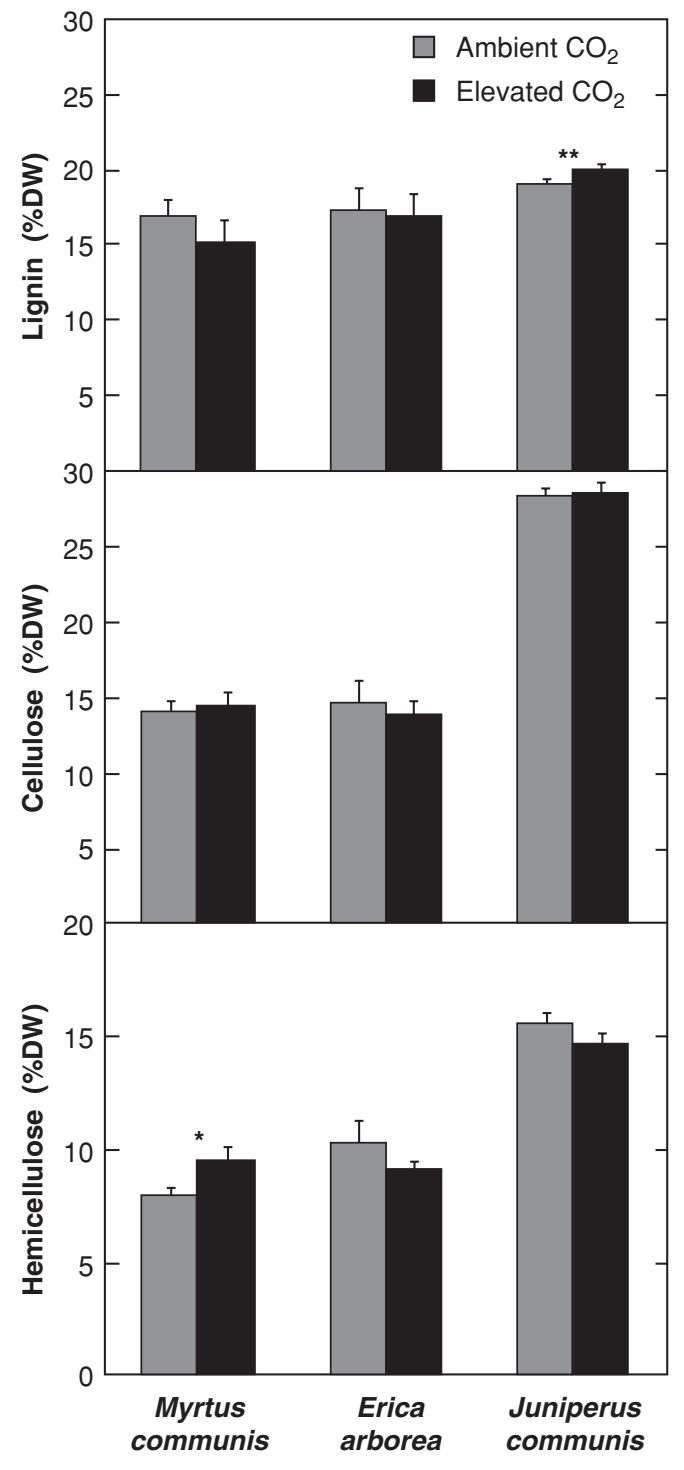

Fig. 2 Effects of elevated $\left[\mathrm{CO}_{2}\right]$ on annual average leaf lignin (top), cellulose (middle), and hemicellulose (bottom). Data presented as percent dry weight $(\% \mathrm{DW})$. Error bars indicate \pm SEM. $n=6$ month averages, calculated on three plants (10-12 leaves pooled together for each plant). ${ }^{*} p<0.05,{ }^{* *} p<0.01$, ANOVA.

Absence of increased CBSSC concentrations at elevated $\left[\mathrm{CO}_{2}\right]$

The most important finding of this study is that although long-term growth at high concentrations of atmospheric $\mathrm{CO}_{2}$ generated some differences in the CBSSC composition of plant leaves depending on species and compounds, the overall CBSSC concentrations did not increase in the $\mathrm{CO}_{2}$ spring site. Even lower phenolic concentrations in plants grown at the $\mathrm{CO}_{2}$ spring site than those in plants grown at the control site were found for one of the studied species-Erica arborea. 


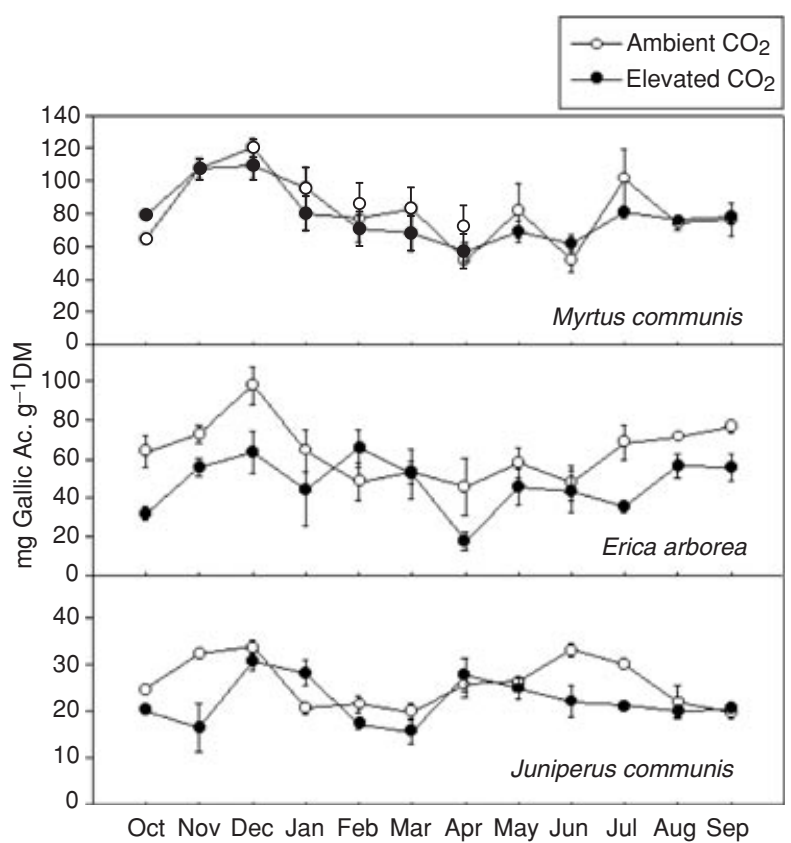

Fig. 3 Seasonal trends in total phenolics concentration (expressed as gallic acid equivalents) measured in leaves of Myrtus communis, Erica arborea, and Juniperus communis plants during 1996-97. Vertical bars indicate standard error of the mean. $n=3$ plants (10-12 leaves pooled together for each plant).

Moreover, these results were not due to a dilution effect because there was neither increased structural or nonstructural carbon nor lipid concentrations (Fig. 1).

These total phenolic data contrast with several previous $\mathrm{CO}_{2}$ experimental studies that were conducted in less natural shorter-term conditions (Peñuelas \& Estiarte 1998). However, the results for lignin and structural polysaccharides, both carbon-based structural compounds that are linked to cell wall, are in agreement with available data (Peñuelas \& Estiarte 1998). All the data are in apparent disagreement with carbon source-sink hypotheses that predict increased CBSSC concentrations at elevated $\mathrm{CO}_{2}$ concentrations (Peñuelas \& Estiarte 1998). These hypotheses assume that elevated $\mathrm{CO}_{2}$ concentrations promote a relative increase of carbon availability that is accumulated in TNCs and CBSSCs when the provided carbon amounts exceed growth requirements (when the source-sink ratio raises) (Bryant et al. 1983; Herms \& Mattson 1992; Peñuelas \& Estiarte 1998).

\section{Interspecific and environmental heterogeneity}

It is difficult to ascertain the specific cause or causes of the absence of elevated $\mathrm{CO}_{2}$ effect on CBSSC concentrations from the available data. Several explanations can be proposed. A likely explanation for the lack of $\mathrm{CO}_{2}$ sensitivity may be related to the various carbon investment strategies available to various plant species, including growth, storage, structural compound, and defense components. The interspecific variability of our data is not surprising; it is also found in many other ecophysiological variables including growth, whose response to elevated $\left[\mathrm{CO}_{2}\right]$ can vary greatly even in co-occurring species of the same functional type and in interaction with abiotic and biotic factors (Bazzaz 1990; Körner 2000). Diverse interspecific responses have also been found for concentrations of several elements in these same plants. Under the elevated $\left[\mathrm{CO}_{2}\right]$ of the spring site, both greater (e.g. in $\mathrm{Ca}, \mathrm{K}, \mathrm{S}, \mathrm{Mg}, \mathrm{Mn}, \mathrm{Al}, \mathrm{Fe}, \mathrm{P}$, and Ti) and lower (e.g. in C, $\mathrm{Ba}, \mathrm{Co}, \mathrm{N}, \mathrm{Cr}, \mathrm{Sr}, \mathrm{P}$, and B) leaf concentrations have been reported. Apart from interspecific differences, there were also different $\mathrm{CO}_{2}$ responses among the various elements and seasons of the year (Peñuelas et al. 2001). These interspecific and seasonal differences show that different plant species may use various available resources within the Mediterranean sites and seasons (Tognetti \& Peñuelas 2001). In fact, the complex natural conditions of the field make it difficult to find exactly identical sites for resource availabilities or environmental conditions, and under such natural conditions, variability in characteristics within and between plant populations can exceed any response to $\mathrm{CO}_{2}$ (Van Gardingen et al. 1997).

\section{Long-term acclimation}

Another explanation for these results comes from a likely long-term adjustment or acclimation of photosynthetic carbon uptake, and finally of most leaf CBSSC concentrations to elevated $\mathrm{CO}_{2}$ over many generations of plant development. Plants have grown in such $\mathrm{CO}_{2}$-enriched environment at least for several centuries (city council archives). Provided that stomatal conductance of plants grown at the $\mathrm{CO}_{2}$ spring site was lower than that of control plants (Tognetti et al. 2000b), the studies of the ${ }^{13} \mathrm{C}$ composition of these plants suggest photosynthetic acclimation under long-term $\mathrm{CO}_{2}$-enriched atmosphere (Miglietta et al. 1998; Tognetti \& Peñuelas 2001), leading to decreased photosynthetic capacity (Miglietta et al. 1998). We have no photosynthetic data for these shrubs, but at the same site, the evergreen Quercus ilex showed significant down-regulation and homeostatic adjustment to elevated $\left[\mathrm{CO}_{2}\right]$ (W.C. Oechel \& C.L. Hinkson, personal communication) in accordance with the results of Miglietta et al. (1995) and Oechel \& Vourlitis (1996). The down-regulated photosynthetic rates may have been enhanced by water stress, which may have been sufficient to decrease carbon uptake relative to the other elements (i.e. restrict growth more than nutrient uptake). The Mediterranean sclerophylls studied in this experiment may have an intrinsic growth strategy that highly prioritizes water saving over carbon uptake. In fact, other 
forest tree species of these sites did not exhibit any increase in above-ground productivity. Possible acclimations to the high $\mathrm{CO}_{2}$ or/and nutrient limitations have been suggested to counteract the positive effect of $\mathrm{CO}_{2}$ under drought stress (Tognetti et al. 2000a).

\section{Complex space and time conditions}

These results showing minimal or species-specific timedependent changes are especially valuable because they were obtained accounting for the complexity of interactions in real life throughout time and space (plant age, neighbours, microbial partners, soil processes, atmospheric conditions...) (Körner 2000). These results showed that increased CBSSC is not a general response to long-term exposure to elevated $\left[\mathrm{CO}_{2}\right]$ in these shrubs. This conclusion is in apparent disagreement with the carbon source-sink hypotheses. Some of the premises of such hypotheses may be unaccomplished under natural field conditions (e.g. microhabitats are heterogeneous for resource availabilities). Moreover, these hypotheses partially ignore the homeostatic nature of organisms and their evolutive history (Hamilton et al. 2001). Our data are in support of acclimation to elevated $\left[\mathrm{CO}_{2}\right]$ of carbon metabolism, with relative lack of carbon excess. This acclimation in leaf chemical composition under elevated $\mathrm{CO}_{2}$ concentration of spring site emphasizes, once more, the importance of conducting natural (field conditions) long-term experiments with plants under elevated $\left[\mathrm{CO}_{2}\right]$. Long-term studies allow the record of homeostatic plant mechanisms and possibly adaptive evolutionary histories. Different growth rates (carbon sink) under various interacting environmental conditions or resource availabilities, and under seasonal and specific variation must be considered, apart from $\left[\mathrm{CO}_{2}\right]$ itself, to study the carbon-nutrient-water relationships under elevated $\left[\mathrm{CO}_{2}\right]$ in shrubs of the Mediterranean environments.

Caution on possible implications for herbivory and decomposition

Many authors have noted the potential significance of $\mathrm{CO}_{2}$-induced changes in leaf nutrient quality for herbivore feeding and development (Fajer et al. 1989; Lincoln et al. 1993; Lindroth et al. 1993; Arnone et al. 1995; Peñuelas \& Estiarte 1998), and for litter decomposition and carbon sequestration in soils (Strain 1985; Rastetter et al. 1992; Comins \& McMurtrie 1993; Schimel 1995; Peñuelas \& Estiarte 1998). Plant digestibility and litter decomposition would be hindered by increased CBSSC concentrations under elevated $\left[\mathrm{CO}_{2}\right]$. However, the results of this investigation suggest caution in attributing increased CBSSC concentrations to elevated $\left[\mathrm{CO}_{2}\right]$ and, in turn, consequences for herbivory and decomposition under long-term $\mathrm{CO}_{2}$ exposure, which is especially relevant to the context of the global carbon budget.

\section{Acknowledgements}

We thank for financial support from CICYT grants CLI99-0479 and REN-2000-0278/CLI (Spanish Government), IMMPACTE grant (DURSI and DMA, Catalan Government), and Fundació Territori i Paisatge (Catalonia).

\section{References}

Allen SE (1989) Chemical Analysis of Ecological Materials. 2nd edn. Blackwell Scientific Publications, Oxford.

Arnone JA III, Zaller JG, Ziegler C, Zandt H, Körner C (1995) Leaf quality and insect herbivory in model tropical plant communities after long-term exposure to elevated atmospheric $\mathrm{CO}_{2}$. Oecologia, 104, 72-78.

Ball AS (1997) Microbial decomposition at elevated $\mathrm{CO}_{2}$ levels: effect of litter quality. Global Change Biology, 3, 379-386.

Bazzaz FA (1990) The responses of natural ecosystems to the rising global $\mathrm{CO}_{2}$ levels. Annual Review of Ecology and Systematics, 21, 167-196.

Bryant JP, Chapin FS III, Klein DR (1983) Carbon/nutrient balance of boreal plants in relation to vertebrate herbivory. Oikos, 40, 357-368.

Comins HN, McMurtrie RE (1993) Long-term response of nutrient limited forests to $\mathrm{CO}_{2}$ enrichment: equilibrium behavior of plant-soil models. Ecological Applications, 3, 666-681.

Damesin C, Rambal S, Joffre R (1997) Between tree variations in leaf $\delta^{13} \mathrm{C}$ of Quercus pubescens and Quercus ilex among Mediterranean habitats with different water availability. Oecologia, 111, 26-35.

Eamus D, Jarvis PG (1989) The direct effects of increasing the global atmospheric $\mathrm{CO}_{2}$ concentration on natural and commercial temperate trees and forests. Advances in Ecological Research, 19, 1-55.

Fajer ED, Bowers MD, Bazzaz FA (1989) The effects of enriched carbon dioxide atmospheres on plant-insect herbivore interactions. Science, 243, 1198-1200.

Farrar JF (1993) Carbon partitioning. In: Photosynthesis and Production in a Changing Environment. A Field and Laboratory Manual (eds Hall DO, Scurlock JMO, Bolhar-Nordenkampf HR, Leegood SC, Long SP), pp. 232-246. Chapman \& Hall.

Hamilton JG, Zangerl AR, DeLucia EH, Berenbaum MR (2001) The carbon-nutrient balance hypothesis: its rise and fall. Ecology Letters, 4, 86-95.

Hättenshwiler S, Miglietta F, Raschi A, Körner C (1997) Thirty years of in situ tree growth under elevated $\mathrm{CO}_{2}$ : a model for future forest responses? Global Change Biology, 3, 463-471.

Hendrix DL, Grange RI (1991) Carbon partitioning and export from mature cotton leaves. Plant Physiology, 95, 228-233.

Herms DA, Mattson WJ (1992) The dilemma of plants: to grow or defend. Quarterly Review of Biology, 67, 283-335.

IPCC (2001) Climate Change 2001: The Scientific Basis. Third Assessment Report of the Intergovernmental Panel on Climate 
Change (IPCC). Cambridge University Press, Cambridge, in press.

Joffre R, Gillon D, Dardenne P, Agneessens R, Biston R (1992) The use of near-infrared spectroscopy in litter decomposition studies. Annales Des Sciences Forestieres, 49, 481-488.

Kattenburg A, Giorgi F, Grassil H et al. (1996) Climate-modelsprojections of future climate. In: Climate Change 1995 - the Science of Climate Change. Contribution of Working Group I to the Second Assessment Report of the Intergovernmental Panel on Climate Change (eds Houghton JT, Meira Filho LG, Callander BA et al.), pp. 285-357. Cambridge University Press, Cambridge, UK.

Koricheva J, Larsson S, Haukioja E, Keinänen M (1998) Regulation of woody plant secondary metabolism by resource availability: hypothesis testing by means of meta-analysis. Oikos, 83, 212-226.

Körner C (2000) Biosphere responses to $\mathrm{CO}_{2}$ enrichment. Ecological Applications, 10 (6), 1590-1619.

Körner C, Miglietta F (1994) Long term effects of naturally elevated $\mathrm{CO}_{2}$ on Mediterranean grassland and forest trees. Oecologia, 99, 343-351.

Lincoln DE, Fajer ED, Johnson RH (1993) Plant-insect herbivore interactions in elevated $\mathrm{CO}_{2}$ environments. Trends in Ecology and Evolution, 8, 64-68.

Lindroth RL, Kinney KK, Platz CL (1993) Responses of deciduous trees to elevated atmospheric $\mathrm{CO}_{2}$ : productivity, phytochemistry and insect performance. Ecology, 74, 763-777.

Marigo (1973) Sur une méthode de fractionnement et d'estimation des composés phénoliques chez les végétaux. Analusis, 2, 106-110.

Meuret M, Dardenne P, Biston R, Poty O (1993) The use of NIR in predicting nutritive value of Mediterranean tree and shrub foliage. Journal of Near Infrared Spectroscopy, 1, 45-54.

Miglietta F, Bandiani M, Bettarini I, van Gardinen P, Selvi F, Raschi A (1995) Preliminary studies of the long-term $\mathrm{CO}_{2}$ response of Mediterranean vegetation around natural $\mathrm{CO}_{2}$ vents. In: Global Change and Mediterranean-type Ecosystems (eds Moren JM, Oechel WC), pp. 102-120. Springer, New York.

Miglietta F, Bettarini I, Raschi A, Körner C, Vaccari FP (1998) Isotope discrimination and photosynthesis of vegetation growing in the Bossoleto $\mathrm{CO}_{2}$ spring. Chemosphere, 36 (4-5), 771-776.

Miglietta F, Raschi A, Bettarini I, Resti R, Selvi F (1993) Natural $\mathrm{CO}_{2}$ springs in Italy: a resource for examining long-term response of vegetation to rising atmospheric $\mathrm{CO}_{2}$ concentrations. Plant, Cell and Environment, 16, 873-878.

O'Neill G, Norby RJ (1996) Litter quality and decomposition rates of foliar litter produced under $\mathrm{CO}_{2}$ enrichment. In: Carbon Dioxide and Terrestrial Ecosystems (eds Koch GW, Mooney HA), pp. 87-103. Academic Press, San Diego, CA.

Oechel WC, Vourlitis GL (1996) Direct effects of elevated $\mathrm{CO}_{2}$ on Arctic plant and ecosystem function. In: Carbon Dioxide and Terrestrial Ecosystems (eds Koch GW, Mooney HA), pp. 163-176. Academic Press, San Diego, CA.

Panichi C, Tongiorgi E (1975) Carbon Isotopic Composition of $\mathrm{CO}_{2}$ from Springs, Fumaroles, Moffetes and Travertines of Central and Southern Italy: a Preliminary Prospection Method of Geothermal Area. In: Second United Nations Symposium on the Development and Use of Geothermal Resources, pp. 815-825, Vol. 1. San Francisco, USA.

Peñuelas J, Estiarte M (1998) Can elevated $\mathrm{CO}_{2}$ affect secondary metabolism and ecosystem function? Trends in Ecology and Evolution, 13, 20-24.

Peñuelas J, Filella I, Tognetti R (2001) Leaf mineral concentrations of Erica arborea, Juniperus communis, and Myrtus communis growing in the proximity of a natural $\mathrm{CO}_{2}$ spring. Global Change Biology, 7, 291-301.

Peñuelas J, Idso SB, Ribas A, Kimball BA (1997) Effects of long-term atmospheric $\mathrm{CO}_{2}$ enrichment on the mineral concentration of Citrus aurantium leaves. New Phytologist, 135, 439-444.

Peñuelas J, Matamala R (1990) Changes in N and S leaf content, stomatal density, and specific leaf area of 14 plant species during the last three centuries of $\mathrm{CO}_{2}$ increase. Journal of Experimental Botany, 41, 1119-1124.

Poorter H, Van Berkel Y, Baxter R, Den Hertog J, Dijkstra P, Gifford RM, Griffin KL, Roumet C, Roy J, Wong C (1997) The effect of elevated $\mathrm{CO}_{2}$ on the chemical composition and constructions costs of leaves of $27 \mathrm{C}_{3}$ species. Plant Cell and Environment, 20, 472-482.

Raiesi FG (1998a) Impacts of elevated atmospheric $\mathrm{CO}_{2}$ on litter quality, litter decomposability and nitrogen turnover rate of two oak species in a Mediterranean forest ecosystem. Global Change Biology, 4, 667-677.

Raiesi FG (1998b) Effects of Elevated Atmospheric $\mathrm{CO}_{2}$ on Soil Organic Carbon Dynamics in a Mediterranean Forest Ecosystem. PhD Dissertation, Wageningen Agricultural University, Wageningen, The Netherlands, $166 \mathrm{pp}$.

Rastetter EB, McKane RB, Shaver GR, Melillo JM (1992) Changes in $\mathrm{C}$ storage by terrestrial ecosystems: how $\mathrm{C}-\mathrm{N}$ interactions restrict responses to $\mathrm{CO}_{2}$ and temperature. Water, Air, and Soil Pollution, 64, 327-344.

Saxe H, Ellsworth DS, Heath J (1998) Tansley Review No. 98. Tree and forest functioning in an enriched $\mathrm{CO}_{2}$ atmosphere. New Phytologist, 139, 395-436.

Schimel DS (1995) Terrestrial ecosystems and the carbon cycle. Global Change Biology, 1, 77-91.

Schulte M (1998) Der Einfluß von erhöhtem atmosphärischen $\mathrm{CO}_{2}$ Konzentrationen auf den $\mathrm{S}_{-}, \mathrm{C}-$ und $\mathrm{N}$ - Metabolismus verschiedener Quercus species. $\mathrm{PhD}$ Thesis. University of Freiburg, Germany.

Strain BR (1985) Physiological and ecological controls on carbon sequestering in terrestrial ecosystems. Biogeochemistry, 1, 219-232.

Tognetti R (1999) The impact of long-term elevated $\mathrm{CO}_{2}$ concentrations on the water relations, stomatal behavior and hydraulic architecture of shrubs, and stem growth of trees in a Mediterranean forest ecosystem. PhD Dissertation. Trinity College, University of Dublin, Dublin, Ireland, 229 pp.

Tognetti R, Cherubini P, Innes J (2000a) Comparative stemgrowth rates of Mediterranean trees under background and naturally enhanced ambient $\mathrm{CO}_{2}$ concentrations. New Phytologist, 146, 59-74.

Tognetti R, Minnocci A, Peñuelas J, Raschi A, Jones MB (2000b) Comparative field water relations of three Mediterranean shrub species co-occurring at a natural $\mathrm{CO}_{2}$ vent. Journal of Experimental Botany, 51, 1131-1146. 
288 J. PEÑUELAS et al.

Tognetti R, Peñuelas J (2001) Carbon and nitrogen isotope discrimination in three Mediterranean shrub species co-occurring at a natural $\mathrm{CO}_{2}$ vent. Acta Oecologica, submitted.

Van Gardingen PR, Grace J, Jeffree CE, Byari SH, Miglietta F, Raschi A, Bettarani I (1997) Long-term effects of enhanced $\mathrm{CO}_{2}$ concentrations on leaf gas exchange: research opportunities using $\mathrm{CO}_{2}$ springs. In: Plant Responses to Carbon Dioxide: evidence from Natural Springs (eds Raschi A, Miglietta F, Tognetti R, van Gardingen PR), pp. 69-86. Cambridge University Press, Cambridge, UK.

Van Soest PJ, Robertson JB (1985) Analysis of Forages and Fibrous Foods: a Laboratory Manual for Animal Science. Cornell University Publications, Cornell, USA. 